\title{
HYDROPEROXIDES FORMATION IN JET FUELS COMING FROM DIFFERENT PRODUCTION PROCESSES IN SIMULATED FUEL SYSTEM OF MODERN AIRCRAFT
}

\author{
TWORZENIE WODORONADTLENKÓW W PALIWACH \\ LOTNICZYCH POCHODZĄCYCH Z RÓŻNYCH \\ PROCESÓW PRODUKCYJNYCH W WARUNKACH \\ SYMULUJĄCYCH UKLAD PALIWOWY \\ WSPÓŁCZESNEGO STATKU POWIETRZNEGO
}

\author{
Jarosław Sarnecki, Bartosz Gawron, Jadwiga Gląb
}

Air Force Institute of Technology, Instytut Techniczny Wojsk Lotniczych

\begin{abstract}
The paper presents issues related to the process of thermal degradation of jet fuel. This process is of a different nature depending on temperature and time, in which the fuel is subjected to thermal action. The standard method for testing the jet fuel thermal stability seems to be insufficient, therefore, the conduct of the research on a dedicated test rig was taken in this paper. The assessment of the fuel degradation process was carried out on the basis of determination of hydroperoxide and acid numbers as signs of the occurred process. The article has been prepared within the research project No. 2011/01/D/ST8/06567 funded by the National Science Centre in Poland.
\end{abstract}

Keywords: jet fuel, thermal stability, non-standard method, hydroperoxide number

Streszczenie: Tematem publikacji sa zagadnienia zwiazane z procesem degradacji termicznej paliwa lotniczego. Proces ten ma odmienny charakter $w$ zależności od temperatury $i$ czasu $w$ jakim paliwo jest poddane działaniu termicznemu. Standardowa metoda badania stabilności termicznej paliwa lotniczego wydaje sie być nie wystarczajaca, dlatego $w$ niniejszej pracy podjęto się przeprowadzenia badań na dedykowanym stanowisku badawczym. Ocene procesu degradacji paliw przeprowadzono $w$ oparciu o wyznaczenie liczby wodoronadtlenkowej $i$ liczby kwasowej jako oznak zaistniatego procesu. Artykut zostat przygotowany w oparciu o rezultaty otrzymane $w$ ramach projektu badawczego $n r$ 2011/01/D/ST8/06567 finansowanego przez Narodowe Centrum Nauki.

Stowa kluczowe: paliwo lotnicze, stabilność termiczna, badania niestandardowe, liczba nadtlenkowa 
Hydroperoxides formation in jet fuels coming from different production processes.. Tworzenie wodoronadtlenków w paliwach lotniczych pochodzacych z różnych...

\section{HYDROPEROXIDES FORMATION IN JET FUELS COMING FROM DIFFERENT PRODUCTION PROCESSES IN SIMULATED FUEL SYSTEM OF MODERN AIRCRAFT}

\section{Introduction}

Jet fuel is a mixture of hydrocarbons from crude oil, which are organic compounds susceptible to oxidation processes. As a result of these processes, the fuel may change its colour, and solid reaction products from oxygen may appear. The results of these phenomena are unfavourable in terms of the aircraft operational safety and the possibility of creating fuel storage reserves. In order to prevent these destructive processes, a package of enriching additives, which contains an additive inhibiting oxidation - the so-called antioxidant - is added to the fuel. The jet fuel susceptibility to reaction with oxygen and the antioxidant efficiency are checked in laboratory tests, which mostly determine the amount of sludge formed in this process.

A typical examination used for testing the jet fuel tendency to oxidation is ASTM D 3241 [1], the so-called JFTOT (Jet Fuel Thermal Oxidative Tester). This method is used in the procedure of assessing the fuel tendency to form sludge in the process of its decomposition in a fuel system. The test allows for the stability measurement at high temperature by assessing the predisposition to formation of sludge, similar to those, which are formed in the actual conditions of the turbine engine's fuel system operation. During the test, the fuel is pumped at constant flow velocity through a heating pipe and then, through a stainless steel filter. As a result of the increased temperature, fuel degradation products, the quantity of which is then estimated, are formed.

However, the results obtained on the basis of this marking do not often correlate with the current problems noted in the aircraft operation. Due to specific assumptions [2,3], this method does not fully reflect the jet fuel actual tendency to degradation at high temperatures. Therefore, in the scope of research on thermal stability, a non-standard approach seems to be necessary.

The fuel thermal degradation process is a very complex phenomenon, which is comprised of many various aspects and mechanisms. This process is of a different nature depending on temperature and time, in which the fuel is subjected to thermal action [4]. In the course of the jet fuel degradation, in the presence of oxygen contained in the air, the hydroperoxides, which constitute compounds with strong oxidation properties, are formed. The content of hydroperoxides in fuel is determined with the use of ASTM D 3703 method [5] and expressed as a hydroperoxide number. These compounds are marked in the form of t-butyl hydroperoxide and cumene hydroperoxide. The hydroperoxide number is a basic signal of the fuel oxidation process allowing for evaluation of its size. Due to the direct destructive impact of hydroperoxides on some types of elastomers contained in the fuel system, the marking of their content is particularly important. 


\section{Research assumptions and concept}

The adopted research concept involved carrying out the following activities:

- Selection and preparation of test fuels.

- Tests on the test rig used for the jet fuel thermal degradation.

- Marking of a hydroperoxide number and an acid number in the laboratory.

In case of the tests, the commercial jet fuel from two different technological processes was selected: Hydrorafinat and Merox. The main difference in the composition of these fuels, which is particularly important in the context of evaluation of oxidation processes, is the content of an antioxidant additive in Hydrorafinat fuel. Before each test, $1,000 \mathrm{ml}$ of given fuel, which was previously filtered in order to remove solid impurities, and then, poured into a clean vessel, was prepared. The fuel prepared in such a way was ready for starting the test on a dedicated test rig.

The construction and measurement capabilities of the rig for testing the jet fuel thermal degradation were presented in detail in the papers [6,7]. Below (Fig. 1), a general view of the test rig together with the marking of individual construction and functional elements were presented.

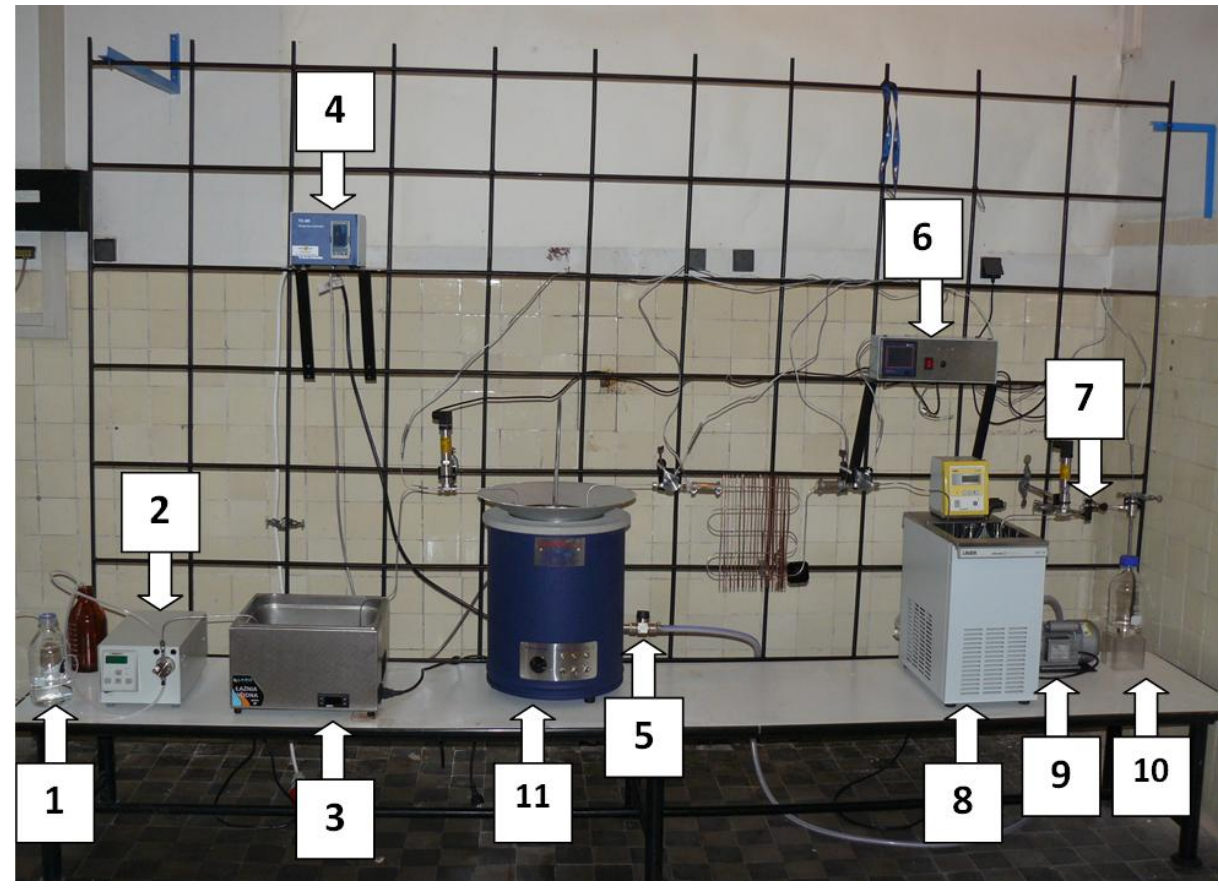

Fig. 1 General view of the test rig:

1. vessel with the tested sample, 2. fuel pump, 3. water bath, 4. temperature controller in the sand bath, 5. sand bath air supply control valve, 6. recorder,

7. pressure valve, 8. cooling thermostat, 9. sand bath air dossing pump, 10. vessel for beakers / vessel for the tested sample, 11. sand bath 
Hydroperoxides formation in jet fuels coming from different production processes.. Tworzenie wodoronadtlenków w paliwach lotniczych pochodzacych z różnych...

In general, the tests involved passing of the prepared fuel samples through the system, in which the fuel at a certain section (in the operating space of the sand bath) was subjected to the thermal impact. A given measuring cycle assumed passing about $720 \mathrm{ml}$ of a given type of fuel each time under specific conditions:

- constant pressure value in the system maintained at the level of $3.5 \mathrm{MPa}$ and a constant value of the fuel flow rate at the level of $3.0 \mathrm{ml} / \mathrm{min}$.,

- variable values of the bath operating temperature in the range of $200-500{ }^{\circ} \mathrm{C}$, and

- constant pressure value in the system maintained at the level of $3.5 \mathrm{MPa}$,

- temperature values of the bath operation determined at the level of $300{ }^{\circ} \mathrm{C}$ and $400{ }^{\circ} \mathrm{C}$,

- variable values of the fuel flow rate: $1,5 \mathrm{ml} / \mathrm{min} ., 3.0 \mathrm{ml} / \mathrm{min}$. and $6 \mathrm{ml} / \mathrm{min}$.

Such selected test conditions were to allow for conducting the broadest possible assessment of their impact on the course of the fuel oxidation process. The variable flow rate value was associated with different time of the test (Table 1) and thus, with different time of the fuel staying in the area of the impact of high temperatures.

Table 1 Fuel testing time depending on determination of the flow rate in the measurement system

\begin{tabular}{|c|c|}
\hline Flow & Test time \\
\hline $1.5 \mathrm{ml} / \mathrm{min}$. & $480 \mathrm{~min} .(8 \mathrm{~h})$ \\
\hline $3.0 \mathrm{ml} / \mathrm{min}$. & $240 \mathrm{~min} .(4 \mathrm{~h})$ \\
\hline $6.0 \mathrm{ml} / \mathrm{min}$. & $120 \mathrm{~min} .(2 \mathrm{~h})$ \\
\hline
\end{tabular}

After the completed test on the dedicated test rig, the fuel sample reached the laboratory as soon as possible in order to mark the hydroperoxide and acid numbers. The implementation of this marking as soon as possible is related to instability of compounds formed as a result of the thermal process. The hydroperoxide number was determined according to the methodology included in [5], and the acid number was determined according to [8].

\section{Test results and assessment of the fuel thermal degradation process}

\section{Characteristics of the jet fuel thermal degradation process}

The reaction process of the hydrocarbons, contained in fuel, with oxygen occurs already at ambient temperature. Its acceleration occurs as a result of the temperature increase. Depending on the temperature value, different processes of fuel degradation occur (Fig. 2.). The division of the temperature scale into ranges allows to distinguish the limits of its stages. The first stage is oxidation at ambient temperature and fuel storage. This process is relatively slow, however, in a longer period of its duration, it leads to formation of the same effects as in case of the processes accelerated by an increase in temperature. 
The subsequent stages include medium temperature oxidation at $50-150^{\circ} \mathrm{C}$, and high temperature oxidation at $150-350^{\circ} \mathrm{C}$. These are the temperature ranges which are most often used in the laboratory tests and allow for assessment of the fuel thermo-oxidative stability in a shorter period of time. The last but one is a transitional stage at $350-400^{\circ} \mathrm{C}$, and finally, a pyrolysis stage, that is decomposition that occurs above the temperature of $400{ }^{\circ} \mathrm{C}[9]$.

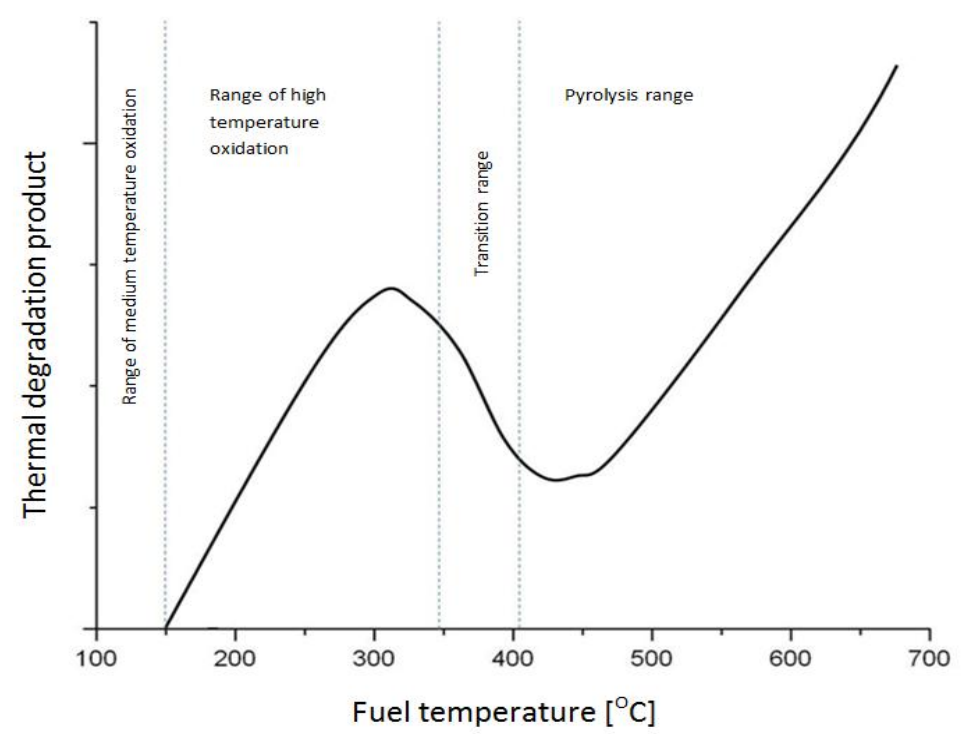

Fig. 2 Jet fuel thermal degradation stages

The oxidation of hydrocarbons contained in the jet fuel related to formation of hydroperoxides occurs on the basis of a free-radical mechanism. As a result of these reactions, alkyl radicals, as well as alkylperoxide radicals, which provide hydroperoxides in the reaction with hydrocarbons, and other products of the reaction with oxygen, are successively formed. In the presented process, the start of a chain free-radical reaction is possible only if there is a trace of a radical initiator in the fuel. The formation of radicals occurs in three major stages of the reaction: initiation, propagation and completion. The reaction process of the free radical with the hydrocarbon begins with penetration of a bond at the carbon and hydrogen site. The ease of the hydrogen atom detachment in this bond determines the reaction velocity. As a result of the oxidation reaction of hydrocarbons, aldehydes, ketones and acids, which eventually lead to the formation of sludge and resins, are created. In order to inhibit the oxidation reaction of hydrocarbons, an antioxidant, the task of which is to bind oxygen and alkylperoxide radicals, and consequently, to lead to detachment and completion of the chain oxidation reaction, is added to the fuel [10]. 
Hydroperoxides formation in jet fuels coming from different production processes.. Tworzenie wodoronadtlenków w paliwach lotniczych pochodzacych z różnych...

\section{Test results}

The obtained results are shown in Figure 3-12. The standardised results of hydroperoxide and acid numbers of Merox and Hydrorafinat fuels in the temperature function, at the constant fuel flow were included in Fig. 3, 4.

The obtained results confirm the occurrence of the formation process of hydroperoxides in the high temperature oxidation range to about $350{ }^{\circ} \mathrm{C}$ (Fig. 3) and its corresponding slow increase in the acid number. It is possible to observe an impact of the antioxidant contained in Hydrorafinat (lower number of hydroxides), especially clear for temperature of $200{ }^{\circ} \mathrm{C}$. Below the temperature of $350{ }^{\circ} \mathrm{C}$, the formation of hydroperoxides rapidly decreases, as a result of less and less quantity of oxygen.

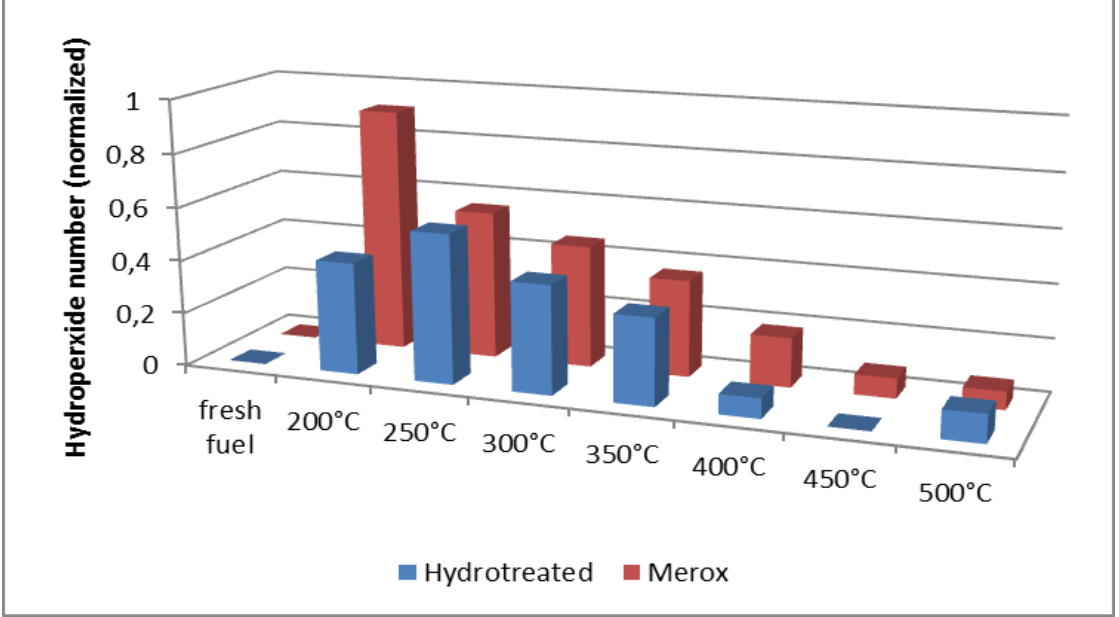

Fig. 3 Change in the hydroperoxide number of jet fuels in the temperature function

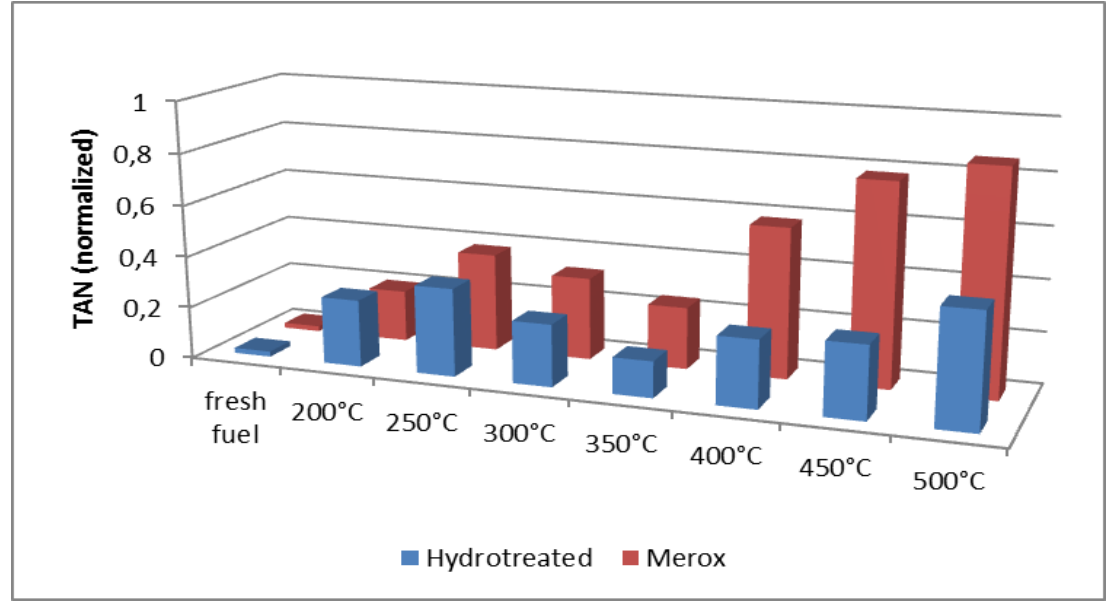

Fig. 4 Change in the acid number of jet fuels in the temperature function 
The acid number in the phase of formation of hydroperoxides in terms of high temperature oxidation (Fig. 4) slightly increases, reaching the maximum for 250 ${ }^{\circ} \mathrm{C}$. Its further increase is observed above $400{ }^{\circ} \mathrm{C}$ (pyrolytic range), with a clearly visible impact of the antioxidant for Hydrorafinat fuel.

In the below drawings, the hydroperoxide number (Fig. 5, 6) and acid number (Fig. 7, 8) results were presented for Merox and Hydrorafinat fuels at $300{ }^{\circ} \mathrm{C}$ and $400{ }^{\circ} \mathrm{C}$ in the variable flow velocity function.

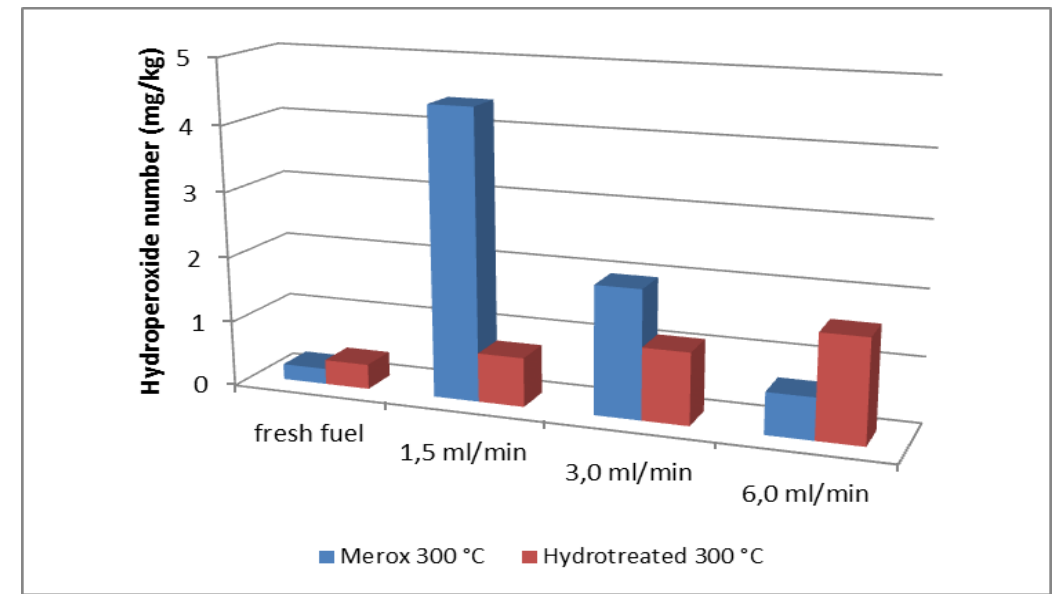

Fig. 5 Change in the hydroperoxide number of jet fuels at $300{ }^{\circ} \mathrm{C}$, in the flow velocity function

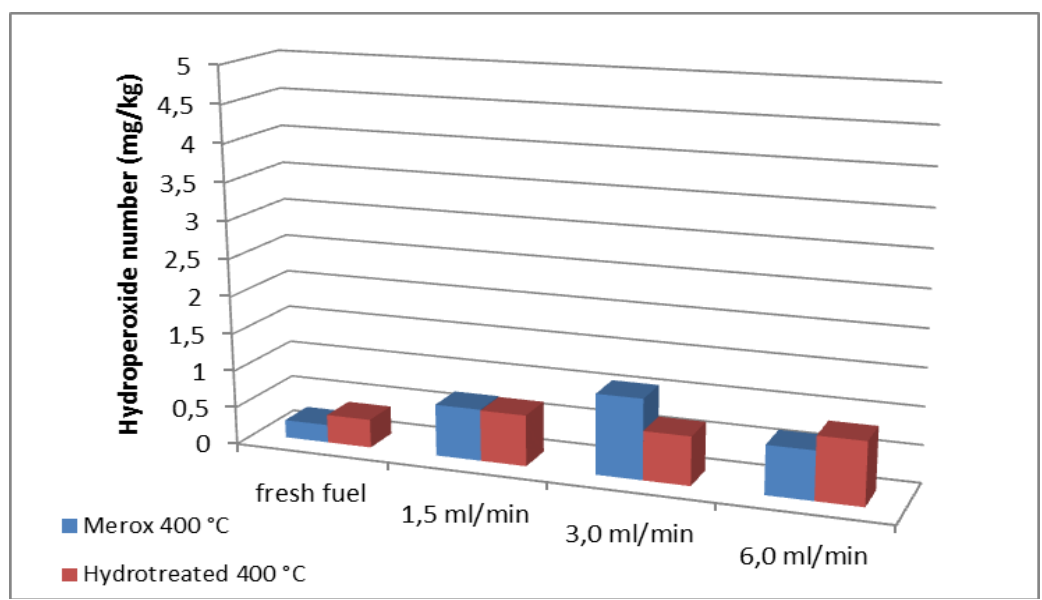

Fig. 6 Change in the hydroperoxide number of jet fuels at $400^{\circ} \mathrm{C}$, in the flow velocity function

In Merox fuel, it is possible to observe the formation of hydroperoxides in a significantly greater number at $300{ }^{\circ} \mathrm{C}$, and at lower flow velocities $(1.5 \mathrm{ml} / \mathrm{min}$. and $3.0 \mathrm{ml} / \mathrm{min}$.) in comparison to Hydrorafinat fuel. 
Hydroperoxides formation in jet fuels coming from different production processes.. Tworzenie wodoronadtlenków w paliwach lotniczych pochodzacych z różnych...

The lower flow rate, that is longer fuel exposure to the impact of the same temperature and the lack of the antioxidant, results in formation of a greater number of hydroperoxides. In this case, the impact of the antioxidant additive in Hydrorafinat fuel is quite clearly noticeable indicating the formation of the lower quantity of hydroperoxides. At temperature of $400{ }^{\circ} \mathrm{C}$ (pyrolytic range), the formation of hydroperoxides in both fuels is low and comparable, and the impact of the antioxidant is unnoticeable.

The acid number for given tested fuel slightly changes together with an increase in the flow velocity, but for the temperature of $400{ }^{\circ} \mathrm{C}$, it reaches nearly twice as high values for Merox fuel in relation to Hydrorafinat.

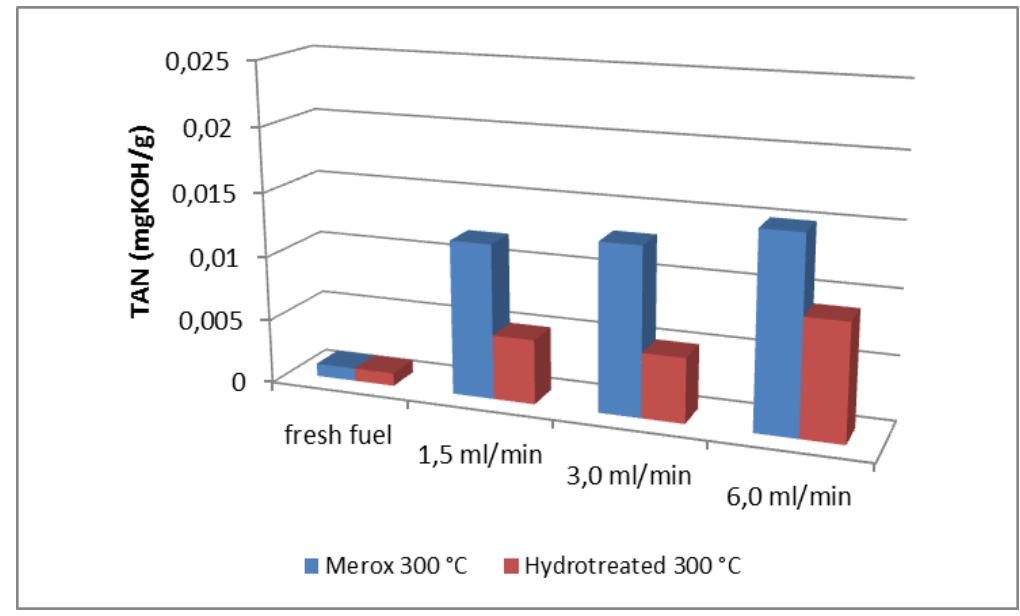

Fig. 7 Change in the acid number of jet fuels at $300{ }^{\circ} \mathrm{C}$, in the flow velocity function

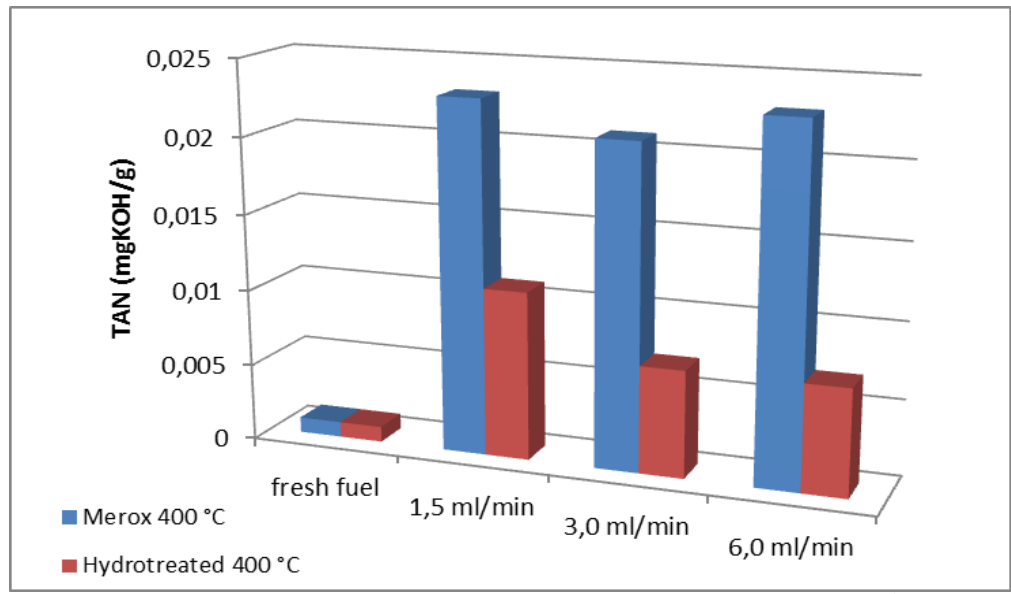

Fig. 8 Change in the acid number of jet fuels at $400{ }^{\circ} \mathrm{C}$, in the flow velocity function 
The other data set in the scope of the hydroperoxide and acid numbers was presented in Fig. 9-12. The obtained results show that the greatest value of the hydroperoxide number was obtained for Merox fuel at $300{ }^{\circ} \mathrm{C}$ and the flow value of $1.5 \mathrm{ml} / \mathrm{min}$. (the longest testing time). For this fuel at the mentioned temperature, the hydroperoxide number value decreases along with an increase in the flow velocity.

The hydroperoxide number values in Hydrorafinat fuel are at the similar low level regardless of the temperature height and the fuel flow velocity. These results confirm effectiveness of the antioxidant additive and a greater tendency to formation of hydroperoxides in unrefined fuel.

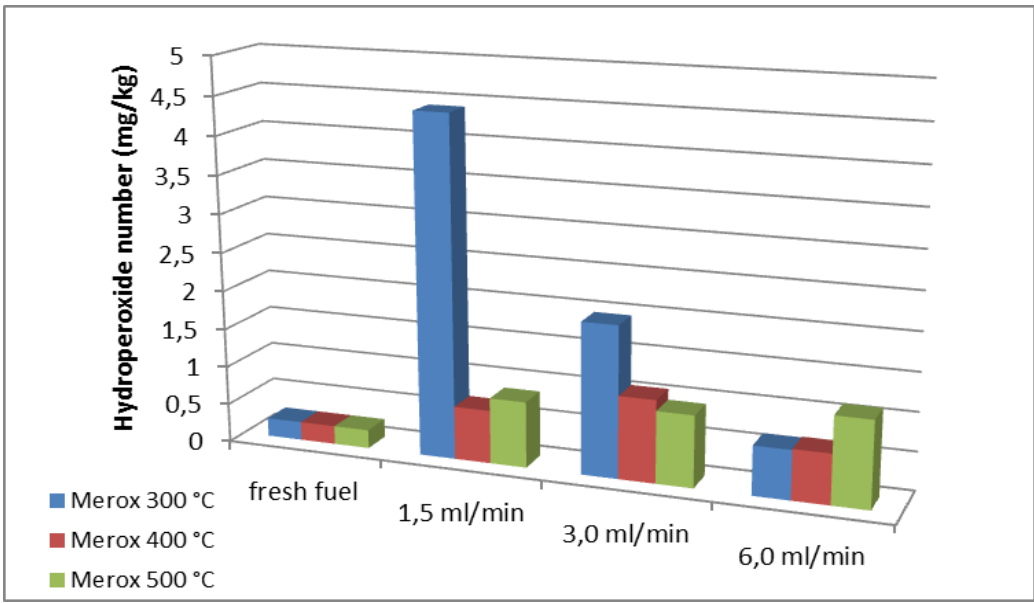

Fig. 9 Change in the hydroperoxide number for Merox fuel in various test conditions

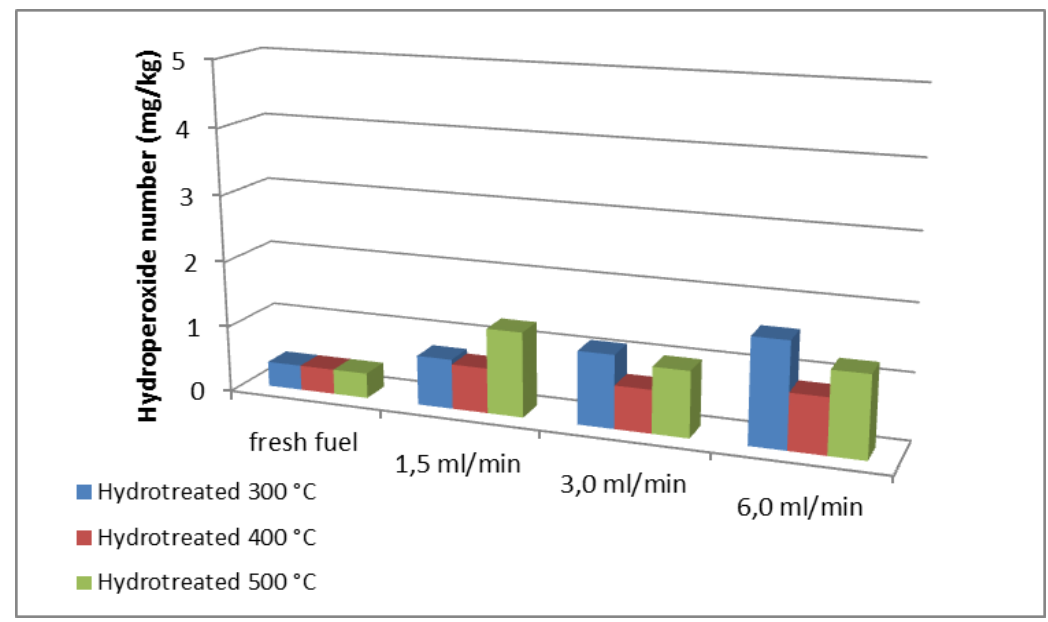

Fig. 10 Change in the hydroperoxide number for Hydrorafinat fuel in various test conditions 
Hydroperoxides formation in jet fuels coming from different production processes.. Tworzenie wodoronadtlenków w paliwach lotniczych pochodzacych z różnych...

The acid number of Merox fuel (Fig. 11) for the temperature of $300{ }^{\circ} \mathrm{C}$ and $400{ }^{\circ} \mathrm{C}$ is within the range of each of these temperatures at a similar level, regardless of the flow velocity, but this number is higher for the temperature of $400{ }^{\circ} \mathrm{C}$. However, at the temperature of $500{ }^{\circ} \mathrm{C}$, the acid number value for Merox fuel is characterised by a decrease together with an increase in the flow velocity.

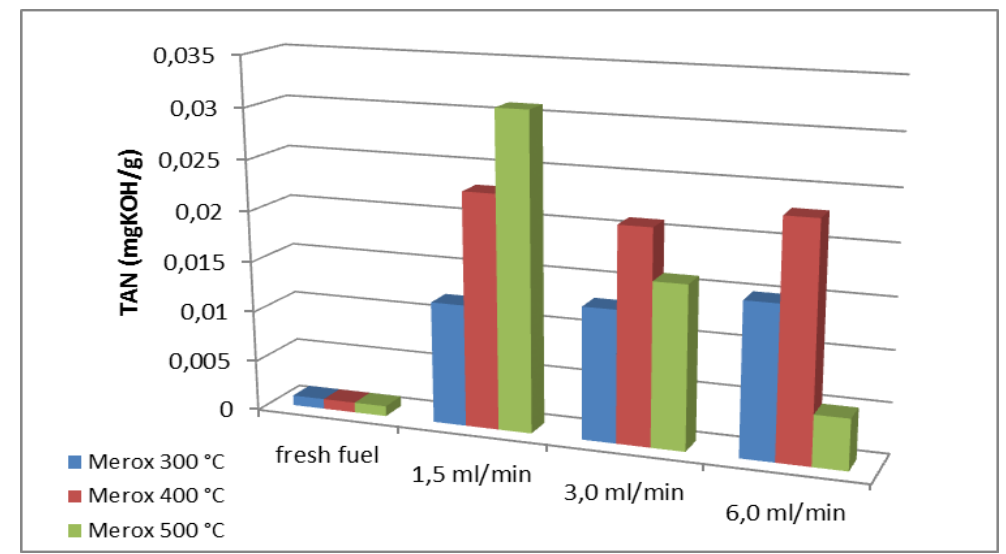

Fig. 11 Change in the acid number of Merox fuel in various test conditions

A similar tendency is observed for Hydrorafinat fuel (Fig. 12), with the difference that the acid number values for this fuel at $300{ }^{\circ} \mathrm{C}$ and $400{ }^{\circ} \mathrm{C}$ are much lower compared to Merox fuel, which may be a result of the antioxidant impact in Hydrorafinat fuel. At $500{ }^{\circ} \mathrm{C}$, effectiveness of the additive impact is imperceptible, and the obtained acid number values are almost the same as for Merox fuel.

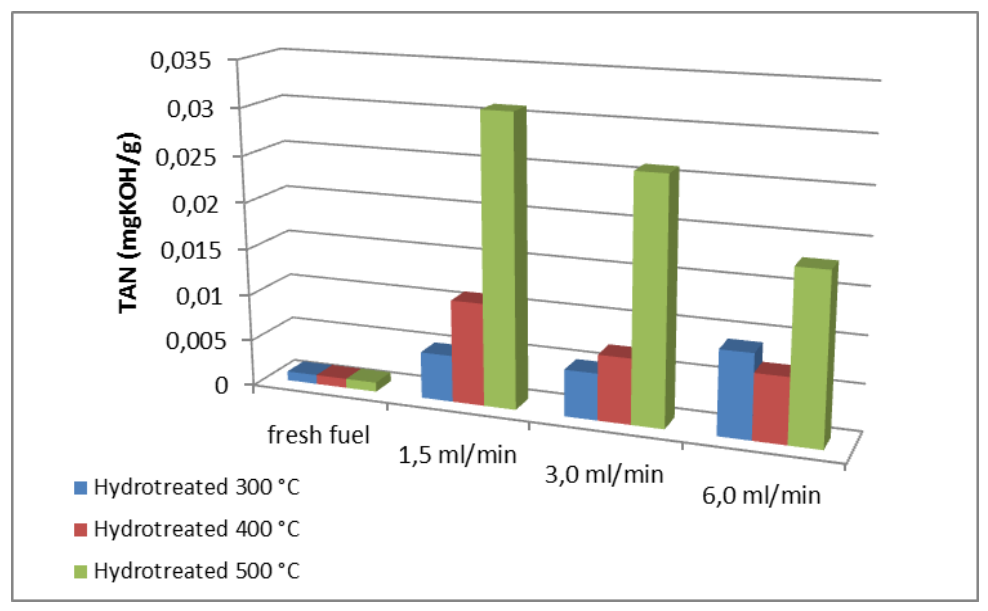

Fig. 12 Change in the acid number of Hydrorafinat fuel in various test conditions 


\section{Conclusion}

The carried-out bench and laboratory tests together with the obtained results of Merox and Hydrorafinat jet fuels clearly indicate the occurrence of their thermal degradation process. The bench tests were implemented in different test conditions, i.e. at different temperatures and velocities of the fuel flow. A measure of assessing the degradation process of tested fuels constituted determination of the hydroperoxide and acid numbers after subjecting them to the impact of high temperatures in the bench system.

The fundamental formation process of hydroperoxides for both tested fuels occurs at about $350{ }^{\circ} \mathrm{C}$. However, the obtained results present that the processing technology of given fuel has an impact on the hydroperoxide number value. It is associated with the jet fuel refining with the use of the antioxidant additive, which plays an important role in the fuel degradation reduction because this additive clearly inhibits the formation of hydroperoxides and decreases the acid number value. The longer test time (low fuel flow rate value), and thus, the longer impact of the increased temperature on the fuel that does not contain the antioxidant additive, is conductive to the formation process of a greater quantity of hydroperoxides.

\section{References}

[1] ASTM D3241 Standard Test Method for Thermal Oxidation Stability of Aviation Turbine Fuels, www.astm.org

[2] Anderson S.D. Edwards T. Harrison W.E.: U.S. Air Force Improved JP-8 Development Program - An Overview, 2nd International Symposium on Aviation Turbine Fuel Specifications, 11-13 May 1993.

[3] Datschefski G.: Critical review of the JFTOT, Aviation fuel: thermal stability requirements, ASTM STP 1138, P. W. Kirklin, P. David, Eds., American Society for Testing and Materials, Philadelphia, 1992.

[4] Sarnecki J: Jet fuels degradation under severe thermal loads, Journal of KONBIN, no 3 (31), pp. 31-40, 2014.

[5] ASTM D3703 Standard Test Method for Hydroperoxide Number of Aviation Turbine Fuels, Gasoline and Diesel Fuels, www.astm.org

[6] Sarnecki J.: Innowacyjne stanowisko badawcze do określania stabilności termicznej paliw lotniczych [Innovative test rig for determining thermal stability of jet fuels], Journal of Konbin, No. 1(29), pp. 15-22, 2014.

[7] Sarnecki J. Gawron B. Kosiak A.: Dokumentacja ruchowa i oprogramowanie stanowiska badawczego do badań procesu degradacji termicznej paliw lotniczych [Operating manual and software of a test rig for studying the thermal degradation process in jet fuels], Sprawozdanie nr 2/55/2014 [Report No. 2/55/2014], Air Force Institute of Technology, 2014.

[8] ASTM D3242 Standard Test Method for Acidity in Aviation Turbine Fuel, www.astm.org 
Hydroperoxides formation in jet fuels coming from different production processes.. Tworzenie wodoronadtlenków w paliwach lotniczych pochodzacych z różnych...

[9] Sarnecki J.: The final report on implementation of the project No. 2011/01/D/ST8/06567 entitled "Badania nad mechanizmami i kinetyką procesu degradacji termicznej paliwa do turbinowych silników lotniczych." ["Research on mechanisms and kinetics of the fuel thermal degradation process for aircraft turbine engines."]

[10] Heneghan S. P., Zabarnick S., Ballal D. R. and Harrison W. E.: JP-8+100: The Development of High-Thermal-Stability Jet Fuel, Journal of Energy Resources Technology 118(3), 170-179, 1996.

\section{The project has been funded by National Science Centre granted with decision no. DEC-2011/01/D/ST8/06567.}

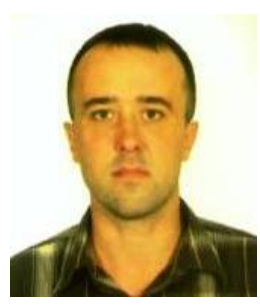

Jarostaw Sarnecki, Ph.D., Eng., graduated Military University of Technology in Warsaw. Since 1999 he has been working in the Air Force Institute of Technology (1999-2002 - Diagnostics Research Division, 2002-2006 - Aero Engines Research Division, since 2006 - Fuels and Lubricants Research Division). His main areas of interest are: combustion of jet fuels, tribology and diagnostic systems for aircraft powerplants. Since 2007 he is a manager of Fuels \&Lubricants Research Division in the AFIT.

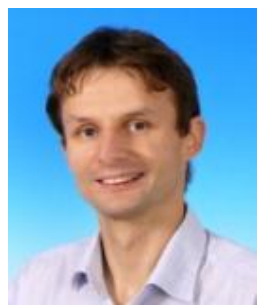

Bartosz Gawron, Ph.D., Eng., a graduate of Military University of Technology in the field of study: mechatronic, specialisation: aircraft and helicopters, in 2008-2012, a doctoral student on the third-degree studies in Military University of Technology at the Faculty of Mechatronics and Aerospace, since September 2012, a doctor of technical sciences in the scientific discipline of mechanics. Currently, a research worker in Air Force Institute of Technology.

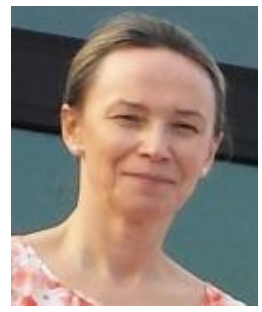

Jadwiga Gtab, M.Sc., a graduate of Chemistry, of the Faculty of Mathematics, Physics and Chemistry of University of Silesia. From 1996 to 2011, she was a head of the Laboratory of Fuels in the Central Laboratory of Petroleum, and then, in the Institute for Fuels and Renewable Energy. Since 2011, a senior research and technical specialist of the Division of Propellants and Greases in Air Force Institute of Technology. 


\section{TWORZENIE WODORONADTLENKÓW W PALIWACH LOTNICZYCH POCHODZĄCYCH Z RÓŻNYCH PROCESÓW PRODUKCYJNYCH W WARUNKACH SYMULUJĄCYCH UKLAD PALIWOWY WSPÓLCZESNEGO STATKU POWIETRZNEGO}

\section{Wstęp}

Paliwo lotnicze jest mieszaniną węglowodorów pochodzących z ropy naftowej, które są związkami organicznymi podatnymi na procesy utleniania. W wyniku tych procesów paliwo może zmienić barwę oraz mogą pojawić się stałe produkty reakcji z tlenem. Skutki tych zjawisk są niekorzystne ze względu na bezpieczeństwo eksploatacji samolotów oraz możliwość tworzenia rezerw magazynowych paliw. W celu przeciwdziałania tym destruktywnym procesom, do paliwa dodawany jest pakiet dodatków uszlachetniających, który zawiera dodatek hamujący utlenianie tzw. antyutleniacz. Podatność paliwa lotniczego do wchodzenia w reakcję z tlenem oraz skuteczność działania antyutleniacza sprawdzana jest $\mathrm{W}$ testach laboratoryjnych określających najczęściej ilość powstałych w tym procesie osadów.

Typowym testem stosowanym do badania tendencji paliwa lotniczego do utleniania jest ASTM D 3241 [1] tzw. JFTOT (Jet Fuel Thermal Oxidative Tester). Metoda stosowana jest $\mathrm{w}$ procedurze oceny skłonności paliwa do tworzenia osadów w procesie jego rozkładu w systemie paliwowym. Badanie pozwala na pomiar $\mathrm{w}$ wysokiej temperaturze stabilności poprzez ocenę predyspozycji do tworzenie osadów, podobnych do tych, które tworzą się $\mathrm{w}$ warunkach rzeczywistych pracy układu paliwowego silnika turbinowego. W czasie trwania testu paliwo jest pompowane przy stałej prędkości przepływu przez rurę grzewczą i następnie przez filtr ze stali nierdzewnej. Na skutek podwyższonej temperatury powstają produkty degradacji paliwa, których ilość jest następnie szacowana.

Wyniki uzyskiwane na podstawie tego oznaczenia nie korelują jednak często $\mathrm{z}$ aktualnymi problemami odnotowywanymi w eksploatacji statków powietrznych. Ze względu na określone założenia [2,3], metoda ta nie odzwierciedla $\mathrm{w}$ pełni rzeczywistej skłonności paliwa lotniczego do degradacji w wysokich temperaturach. Zatem w zakresie badań nad stabilnością termiczną konieczne wydaje się podejście niestandardowe.

Proces termicznej degradacji paliwa jest zjawiskiem bardzo złożonym, składającym się $\mathrm{z}$ wielu różnych aspektów i mechanizmów. Proces ten ma odmienny charakter $\mathrm{w}$ zależności od temperatury i czasu $\mathrm{w}$ jakim paliwo jest poddane działaniu termicznemu [4].

$\mathrm{W}$ przebiegu degradacji paliwa lotniczego, w obecności tlenu zawartego w powietrzu, tworzą się wodoronadtlenki, związki o silnych własnościach utleniających. Zawartość wodoronadtlenków w paliwie określana jest przy pomocy metody ASTM D 3703 [5] i wyrażana jako liczba wodoronadtlenkowa. Związki te oznaczane są w postaci wodoronadtlenku t-butylowego oraz wodoronadtlenku kumenu. 
Hydroperoxides formation in jet fuels coming from different production processes.. Tworzenie wodoronadtlenków w paliwach lotniczych pochodzacych z różnych...

Liczba wodoronadtlenkowa jest podstawowym sygnałem o procesie utleniania się paliwa, pozwalając na ocenę jego wielkości. Ze względu na bezpośredni destrukcyjny wpływ wodoronadtlenków na niektóre rodzaje elastomerów znajdujących się w układzie paliwowym, oznaczenie ich zawartości jest szczególnie istotne.

\section{Założenia i koncepcja badań}

Przyjęta koncepcja badań zakładała wykonanie następujących czynności:

- Wytypowanie i przygotowanie testowych paliw.

- Badania na stanowisku do degradacji termicznej paliwa lotniczego.

- Oznaczenie w laboratorium liczby wodoronadtlenkowej i liczby kwasowej.

Do badań wytypowano komercyjne paliwo lotnicze pochodzące $\mathrm{z}$ dwóch odmiennych procesów technologicznych: Hydrorafinat i Merox. Zasadniczą różnicą w składzie tych paliw, szczególnie istotną w kontekście oceny procesów utleniania, jest zawartość dodatku antyutleniającego w paliwie Hydrorafinat. Przed każdym badaniem przygotowywano $1000 \mathrm{ml}$ danego paliwa, które było wcześniej filtrowane $\mathrm{w}$ celu usunięcia stałych zanieczyszczeń i następnie zlewane do czystego pojemnika. Tak przygotowane paliwo było gotowe do rozpoczęcia danego testu na dedykowanym stanowisku badawczym.

Budowa i możliwości pomiarowe stanowiska do badania degradacji termicznej paliwa lotniczego zostały przedstawiona szczegółowo w pracach [6,7]. Poniżej (Rys. 1) zaprezentowano ogólny widok stanowiska wraz $\mathrm{z}$ zaznaczeniem poszczególnych elementów konstrukcyjnych i funkcjonalnych.

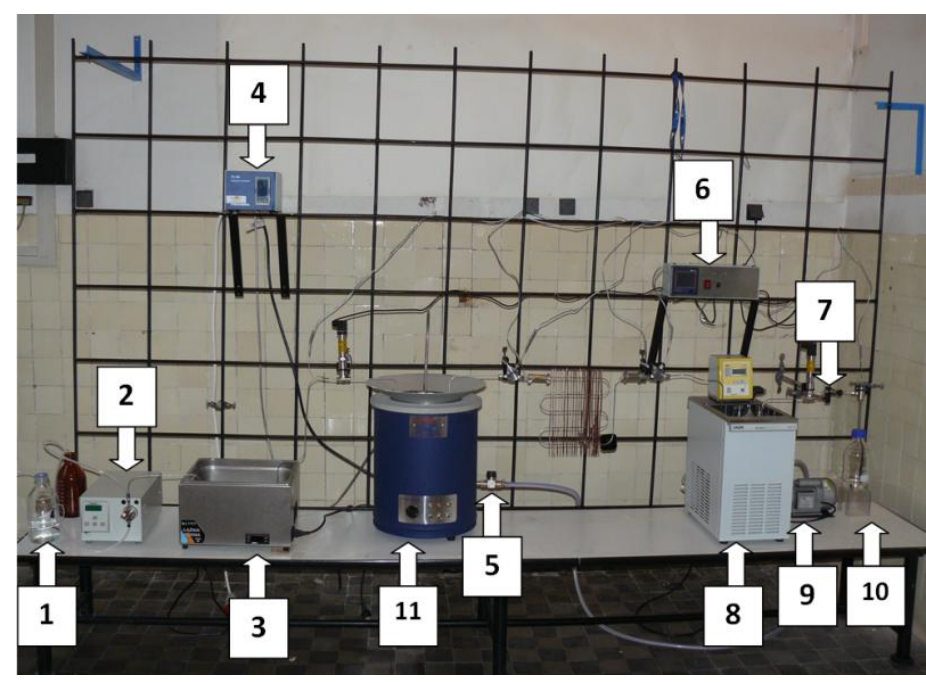

Rys. 1 Widok ogólny stanowiska badawczego:

1. naczynie z badana próbką, 2. pompa paliwa, 3. taźnia wodna,

4. kontroler temperatury w łaźni piaskowej, 5. zawór sterowania doplywem

powietrza do łaźni piaskowej, 6. rejestrator, 7. zawór ciśnieniowy,

8. termostat chtodzacy, 9. pompka dozujaca powietrze do taźni piaskowej,

10. naczynie na zlewki / naczynie na badana próbkę, 11. taźnia piaskowa 
Ogólnie badania polegały na przepuszczeniu przygotowanych próbek paliw przez instalację, w której paliwo na określonym odcinku (w przestrzeni roboczej łaźni piaskowej) było poddawane oddziaływaniu termicznemu. Dany cykl pomiarowy zakładał przepuszczenie każdorazowo ok. $720 \mathrm{ml}$ danego typu paliwa w określonych warunkach:

- stała wartość ciśnienia w instalacji utrzymywana na poziomie 3.5 MPa oraz stała wartość wydatku paliwa na poziomie $3.0 \mathrm{ml} / \mathrm{min}$,

- zmienne wartości temperatury pracy łaźni w zakresie $200-500^{\circ} \mathrm{C}$. oraz

- stała wartość ciśnienia w instalacji utrzymywana na poziomie $3.5 \mathrm{MPa}$,

- wartości temperatury pracy łaźni ustalone na poziomie $300^{\circ} \mathrm{C}$ i $400{ }^{\circ} \mathrm{C}$,

- zmienne wartości wydatku paliwa: $1,5 \mathrm{ml} / \mathrm{min}, 3.0 \mathrm{ml} / \mathrm{min} \mathrm{i} 6 \mathrm{ml} / \mathrm{min}$.

Tak dobrane warunki badania miały za zadanie umożliwienie przeprowadzenia jak najszerszej oceny ich wpływu na przebieg procesu utleniania paliwa. Zmienna wartość wydatku związana była z różnym czasem trwania badania (Tabela 1) i tym samym $\mathrm{z}$ różnym czasem przebywania paliwa w strefie oddziaływania wysokich temperatur.

Tabela 1 Czas badania paliwa w zależności od ustalenia wydatku przeptywu w uktadzie pomiarowym

\begin{tabular}{|c|c|}
\hline Przeplyw & Czas badania \\
\hline $1,5 \mathrm{ml} / \mathrm{min}$ & $480 \min (8 \mathrm{~h})$ \\
\hline $3,0 \mathrm{ml} / \mathrm{min}$ & $240 \min (4 \mathrm{~h})$ \\
\hline $6,0 \mathrm{ml} / \mathrm{min}$ & $120 \min (2 \mathrm{~h})$ \\
\hline
\end{tabular}

Po zakończonym teście na dedykowanym stanowisku, próbka paliwa trafiała w możliwie jak najkrótszym czasie do laboratorium w celu oznaczenia liczby wodoronadtlenkowej i kwasowej. Wykonanie tego oznaczenia możliwie jak najszybciej związane jest z nietrwałością związków powstałych na skutek procesu termicznego. Liczbę wodoronadtlenkową określano według metodyki zawartej w [5], a liczbę kwasową według [8].

\section{Wyniki badań i ocena procesu degradacji termicznej paliwa}

\section{Charakterystyka procesu degradacji termicznej paliwa lotniczego}

Proces wchodzenia węglowodorów zawartych $\mathrm{w}$ paliwie $\mathrm{w}$ reakcje $\mathrm{z}$ tlenem zachodzi już $\mathrm{w}$ temperaturze otoczenia. Jego przyspieszenie następuje na skutek wzrostu temperatury. W zależności od wartości temperatury mamy do czynienia z różnymi procesami degradacji paliwa (Rys. 2). Podział skali temperatury na zakresy pozwala na wyróżnienie granic jego etapów. Pierwszy etap jest utlenianiem w temperaturze otoczenia i przechowywania paliwa, proces jest stosunkowo wolny, niemniej jednak w dłuższym okresie jego trwania prowadzi do powstawania takich samych skutków jak procesy przyspieszane poprzez wzrost temperatury. 
Hydroperoxides formation in jet fuels coming from different production processes.. Tworzenie wodoronadtlenków w paliwach lotniczych pochodzacych z różnych...

Kolejnymi etapami są utlenianie średniotemperaturowe zachodzące w temperaturze $50-150^{\circ} \mathrm{C}$ i wysokotemperaturowe $\mathrm{w}$ temperaturze $150-350^{\circ} \mathrm{C}$. Sa to te zakresy temperatur, które najczęściej są wykorzystywane w testach laboratoryjnych, pozwalających na ocenę stabilności termooksydacyjnej paliwa w krótszym czasie. Jako przedostatni jest etap przejściowy w temperaturze $350-400^{\circ} \mathrm{C}$ i w końcu etap pirolizy, czyli rozkładu zachodzący powyżej temperatury $400^{\circ} \mathrm{C}[9]$.

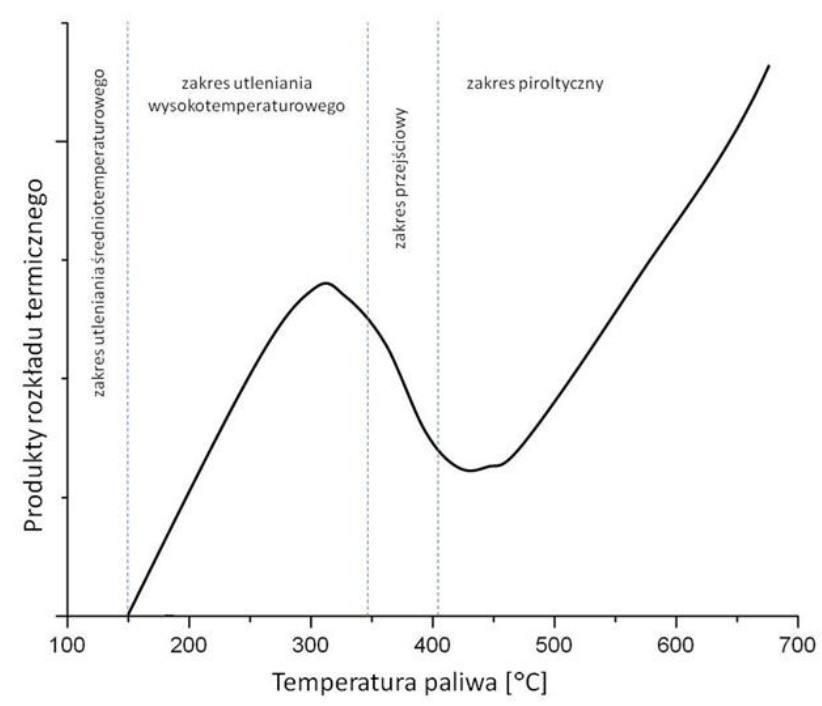

Rys. 2 Etapy degradacji termicznej paliw lotniczych

Utlenianie węglowodorów zawartych w paliwie lotniczym związane $\mathrm{z}$ powstawaniem wodoronadtlenków, zachodzi $\mathrm{w}$ oparciu o mechanizm wolnorodnikowy. W wyniku tych reakcji powstają kolejno rodniki alkilowe, rodniki alkilonadtlenkowe, które w reakcji z węglowodorami dają wodoronadtlenki $\mathrm{i}$ inne produkty reakcji $\mathrm{z}$ tlenem. W przedstawionym procesie rozpoczęcie łańcuchowej reakcji wolnorodnikowej jest możliwie dopiero wówczas, gdy w paliwie pojawi się ślad rodnikowego inicjatora. Powstawanie rodników zachodzi w trzech głównych etapach reakcji: inicjacji, propagacji i zakończenia. Proces wejścia $\mathrm{w}$ reakcję wolnego rodnika $\mathrm{z}$ węglowodorem rozpoczyna się od penetracji wiązania w miejscu węgiel - wodór. Łatwość oderwania atomu wodoru w tym wiązaniu determinuje szybkość zajścia reakcji. Na skutek reakcji utleniania węglowodorów powstają aldehydy, ketony i kwasy, które w końcu prowadzą do powstawania osadów i żywic. W celu zahamowania reakcji utleniania węglowodorów, do paliwa dodawany jest antyutleniacz, którego zadaniem jest wiązanie tlenu i rodników alkilonadtlenkowych, a w konsekwencji doprowadzenie do przerywania i zakończenia reakcji łańcuchowej utleniania [10]. 


\section{Wyniki testów}

Uzyskane wyniki badań przedstawiono na Rys. 3-12. Znormalizowane wyniki liczby nadtlenkowej $\mathrm{i}$ kwasowej paliwa Merox $\mathrm{i}$ Hydrorafinat $\mathrm{w}$ funkcji temperatury, przy stałym przepływie paliwa zawarto na Rys. 3, 4 .

Uzyskane rezultaty potwierdzają zachodzenie procesu powstawania wodoronadtlenków w zakresie wysokotemperaturowego utleniania do około $350{ }^{\circ} \mathrm{C}$ (Rys. 3) i odpowiadającemu mu powolnemu wzrostowi liczby kwasowej. Można zaobserować wpływ zawartego antyutleniacza w Hydrorafinacie (mnijesza liczba wodorotlenków), szczególnie wyraźny dla temperatury $200{ }^{\circ} \mathrm{C}$. Powyżej temperatury $350{ }^{\circ} \mathrm{C}$ tworzenie się wodoronadtlenków gwałtwnie maleje, na skutek coraz mniejszej ilości tlenu.

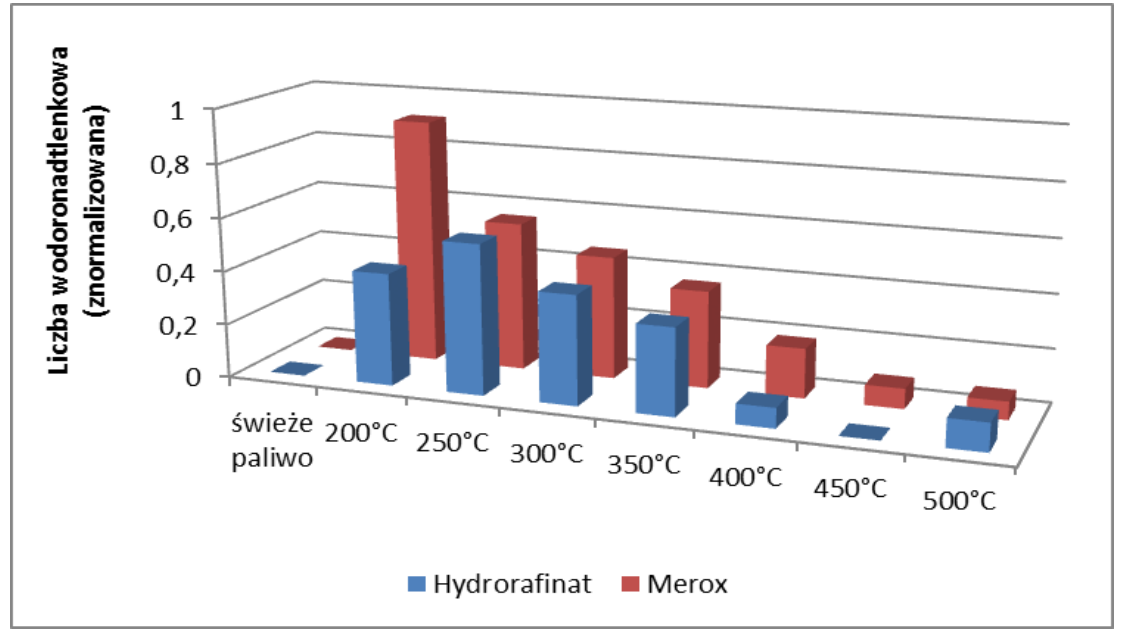

Rys. 3 Zmiana liczby wodoronadtlenkowej paliw lotniczych w funkcji temperatury

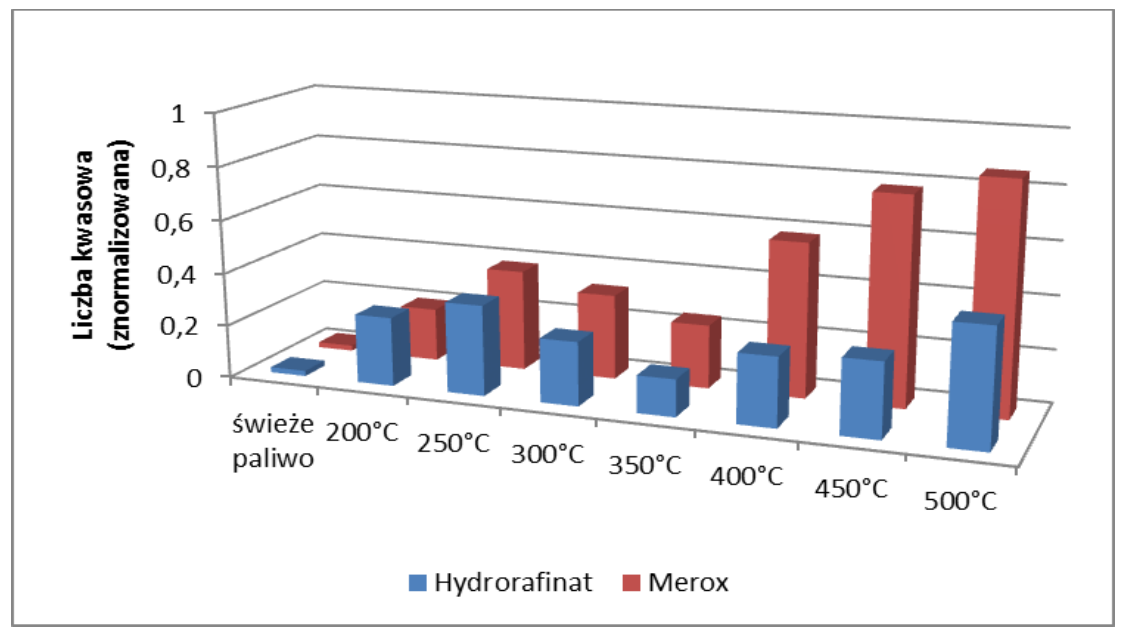

Rys. 4 Zmiana liczby kwasowej paliw lotniczych $w$ funkcji temperatury 
Hydroperoxides formation in jet fuels coming from different production processes.. Tworzenie wodoronadtlenków w paliwach lotniczych pochodzacych z różnych...

Liczba kwasowa $\mathrm{w}$ fazie powstawania wodoronadtlenków w zakresie utlenieniania wysokotemperaturowego (Rys. 4) rośnie nieznacznie osiągajac maksimum dla $250{ }^{\circ} \mathrm{C}$. Dalszy jej wzrost jest obserwowany powyżej $400{ }^{\circ} \mathrm{C}$ (zakres pirolityczny), z wyraźnie widocznym wpływem antyutleniacza dla paliwa Hydrorafinat.

Na rysunkach poniżej przedstawiono wyniki liczby wodornadtlenkowej (Rys. 5,6) i liczby kwasowej (Rys. 7,8) dla paliwa Merox i Hydrorafinat w temperaturze $300{ }^{\circ} \mathrm{C}$ i $400{ }^{\circ} \mathrm{C}$ w funkcji zmiennej predkości przepływu.

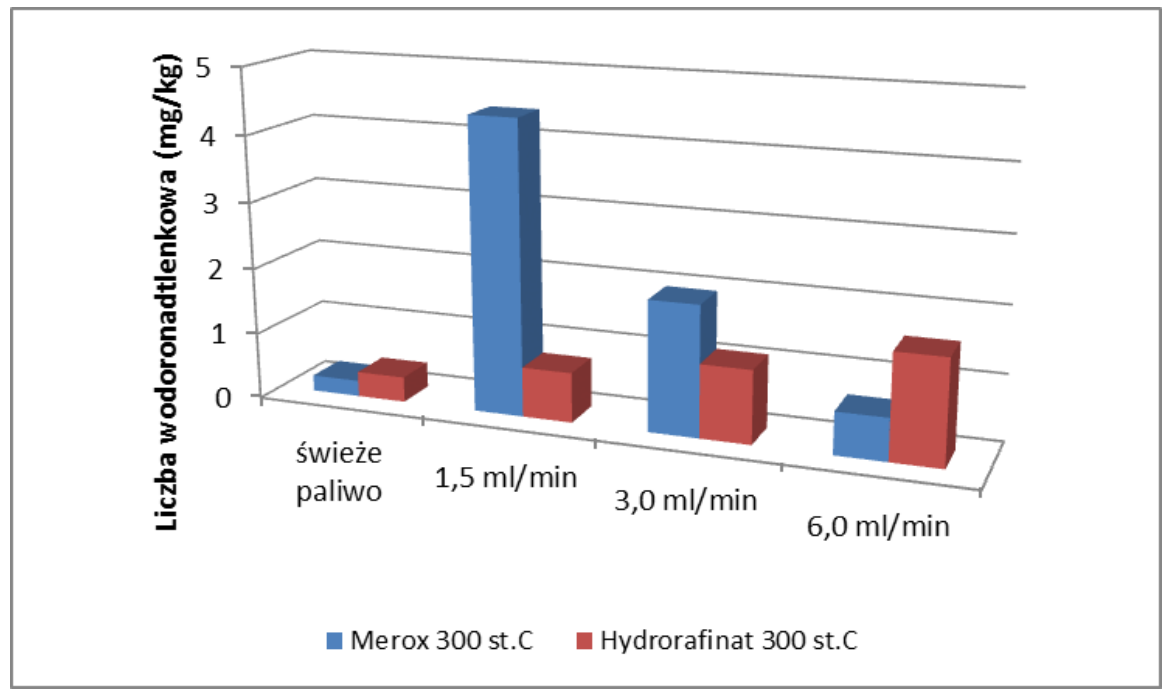

Rys. 5 Zmiana liczby wodoronadtlenkowej paliw lotniczych w temperaturze $300^{\circ} \mathrm{C}$, w funkcji prędkości przeptywu

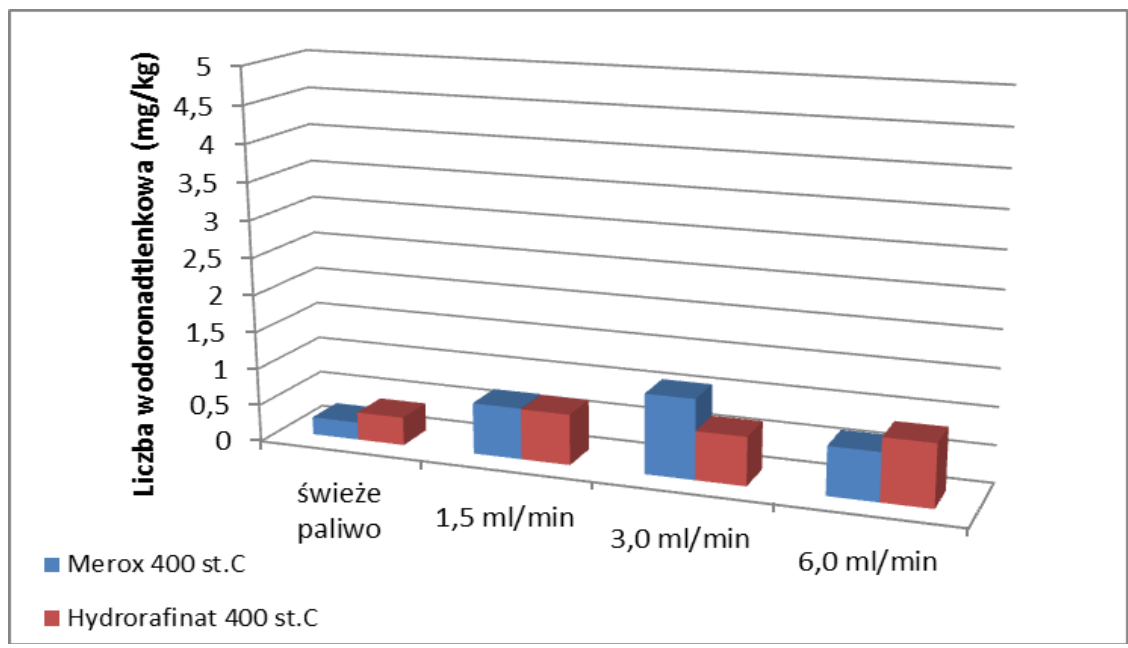

Rys. 6 Zmiana liczby wodoronadtlenkowej paliw lotniczych w temperaturze $400^{\circ} \mathrm{C}$, w funkcji prędkości przeptywu 
W paliwie Merox obserwujemy powstawanie wodoronadtlenków w znacznie wiekszej ilosci w temperaturze $300{ }^{\circ} \mathrm{C}$ i przy mniejszych prędkościach przepływu $(1,5 \mathrm{ml} / \mathrm{min}$ i $3,0 \mathrm{ml} / \mathrm{min})$ w porównaniu do paliwa Hydrorafinat. Mniejszy wydatek, czyli dłuzsze narażenie paliwa na odziaływanie tej samej temperatury i brak antyutleniacza, skutkuje wytworzeniem wiekszej ilości wodoronatlenków. Wpływ dodatku antyutleniacza w paliwie Hydrorafinat jest w tym przypadku dość wyraźnie zauważalny, wskazując na powstanie mniejszej ilości wodoronadtlenków. $\mathrm{W}$ temperaturze $400{ }^{\circ} \mathrm{C}$ (zakres pirolityczny) powstawanie wodoronadtlenków $\mathrm{w}$ obu paliwach jest niewielkie i porównywalne, a wpływ antyutleniacza niezauważalny.

Liczba kwasowa dla danego testowego paliwa zmienia się nieznacznie wraz ze wzrostem predkosci przepływu przy czym dla temperatury $400{ }^{\circ} \mathrm{C}$ osiąga prawie dwukrotnie wyższe wartosci dla paliwa Merox w odniesieniu do Hydrarafinatu.

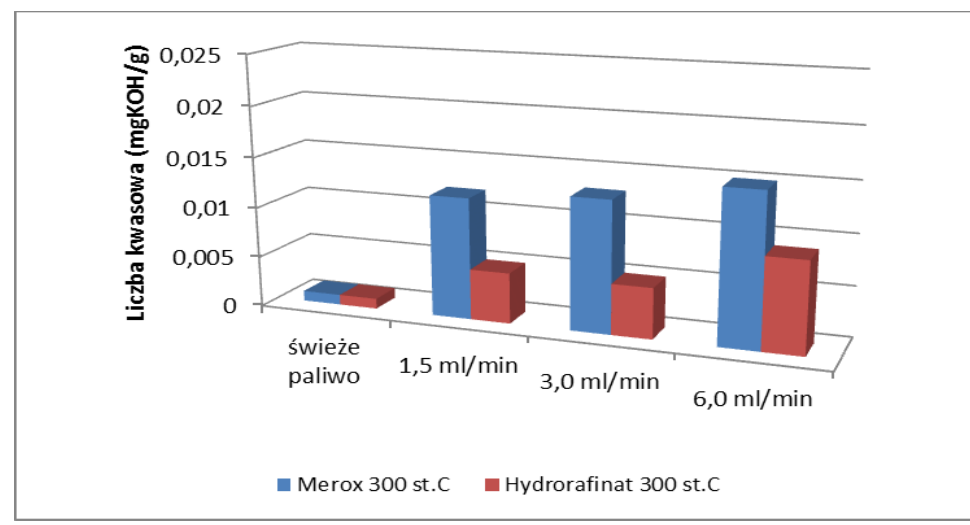

Rys. 7 Zmiana liczby kwasowej paliw lotniczych w temperaturze $300^{\circ} \mathrm{C}$, w funkcji prędkości przepływu

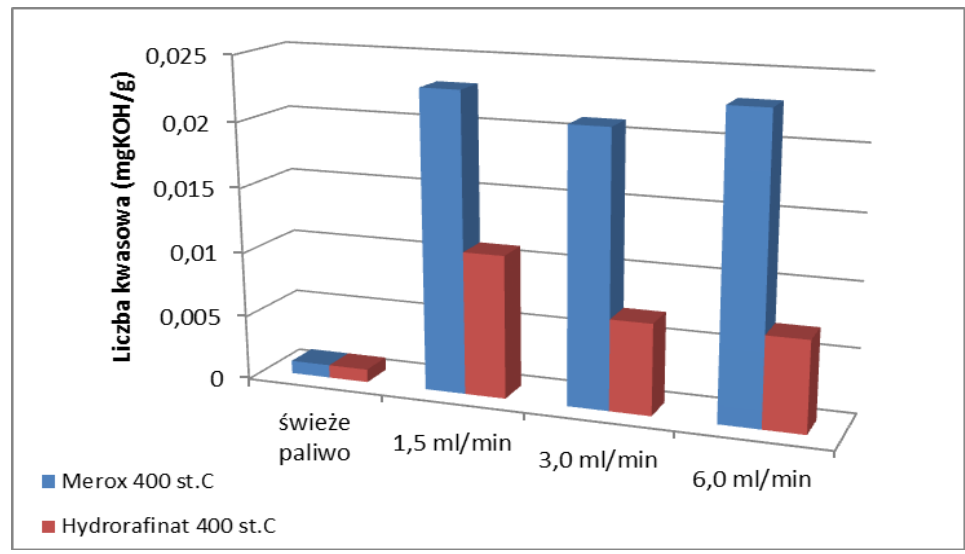

Rys. 8 Zmiana liczby kwasowej paliw lotniczych w temperaturze $400^{\circ} \mathrm{C}, w$ funkcji prędkości przeptywu 
Hydroperoxides formation in jet fuels coming from different production processes.. Tworzenie wodoronadtlenków w paliwach lotniczych pochodzacych z różnych...

Inne zestawienie danych w zakresie liczby wodoronadtlenkowej i liczby kwasowej przedstawiono na Rys. 9-12. Otrzymane wyniki wskazują, że największa wartość liczby wodoronadtlenkowej otrzymana została dla paliwa Merox w temperaturze $300{ }^{\circ} \mathrm{C}$ i wartości przepływu $1,5 \mathrm{ml} / \mathrm{min}$ (najdłuższy czas badania). Dla tego paliwa w tej temperaturze wraz ze wzrostem prędkości przepływu, wartość liczby wodoronadtlenkowej ulega zmniejszeniu.

Wartości liczby wodoronadtlenkowej w paliwie Hydrorafinat, są na podobnym, niskim poziomie, bez względu na wysokość temperatury i prędkość przepływu paliwa. Wyniki te potwierdzają skuteczność działania dodatku antyutleniacza oraz większą skłonność do tworzenia wodoronadtlenków w paliwie nieuszlachetnionym.

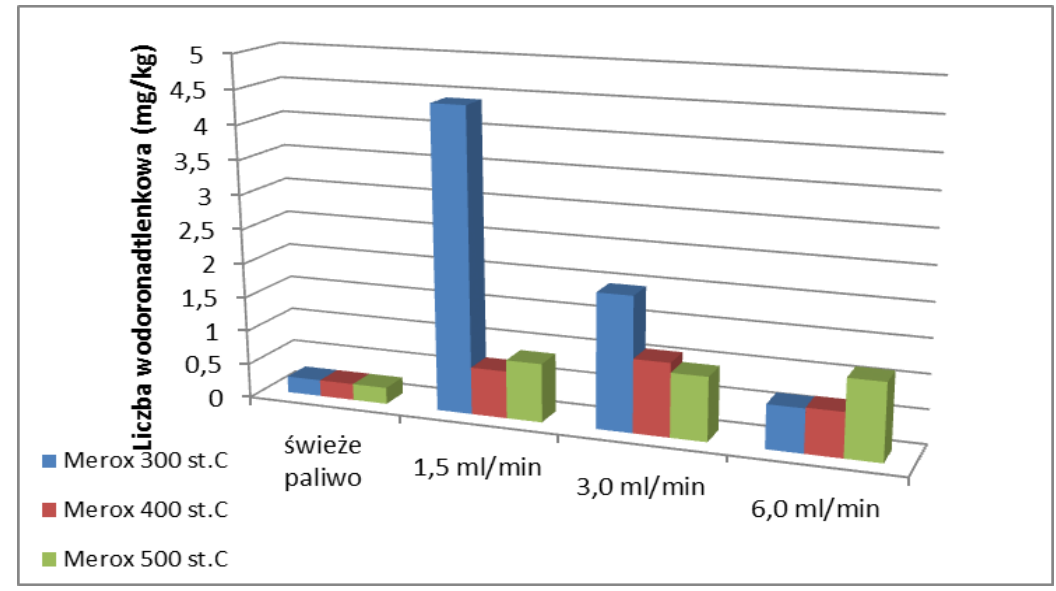

Rys. 9 Zmiana liczby wodoronadtlenkowej dla paliwa Merox w różnych warunkach badania

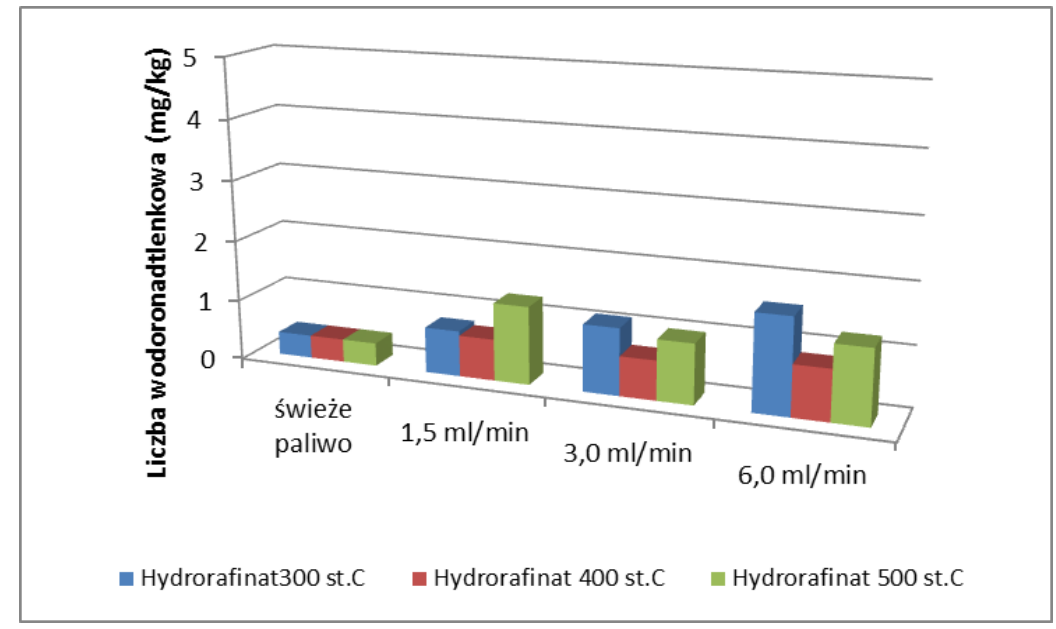

Rys. 10 Zmiana liczby wodoronadtlenkowej dla paliwa Hydrorafinat w różnych warunkach badania 
Liczba kwasowa paliwa Merox (Rys. 11) dla temperatury $300{ }^{\circ} \mathrm{C}$ i $400{ }^{\circ} \mathrm{C}$ jest w zakresie każdej $\mathrm{z}$ tych temperatur na podobnym poziomie, bez względu na prędkość przepływu, przy czym liczba ta jest wyższa dla temperatury $400{ }^{\circ} \mathrm{C}$. Natomiast $\mathrm{w}$ temperaturze $500{ }^{\circ} \mathrm{C}$ wartość liczby kwasowej dla paliwa Merox charakteryzuje się spadkiem wraz z wzrostem prędkości przepływu.

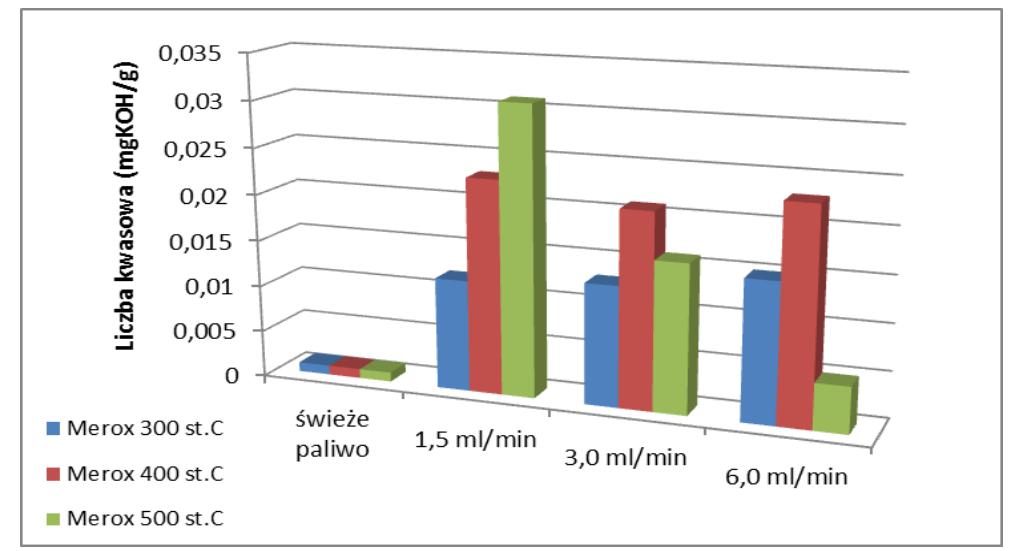

Rys. 11 Zmiana liczby kwasowej paliwa Merox w różnych warunkach badania

Podobną tendencję obserwujemy dla paliwa Hydrorafinat (Rys. 12) z tą różnica, że wartości liczby kwasowej dla tego paliwa w temperaturach $300{ }^{\circ} \mathrm{C}$ i $400{ }^{\circ} \mathrm{C}$ są znacznie mniejsze $\mathrm{w}$ porównaniu do paliwa Merox, co może być wynikiem działania antyutleniacza $\mathrm{w}$ paliwie Hydrorafinat. W temperaturze $500{ }^{\circ} \mathrm{C}$ skuteczność działania dodatku jest niezauważalna, a otrzymane wartości liczby kwasowej są prawie identyczne jak dla paliwa Merox.

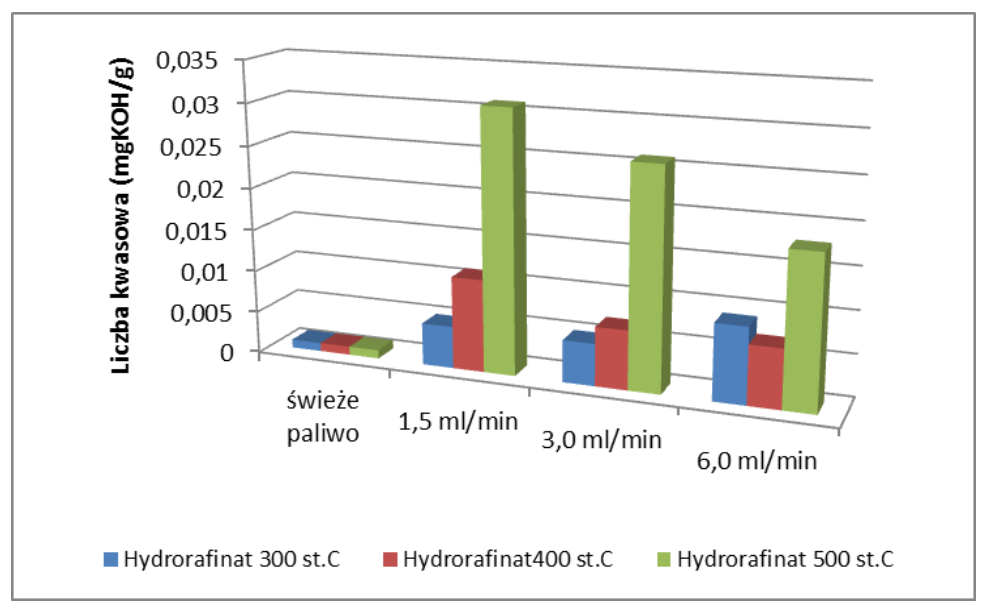

Rys. 12 Zmiana liczby kwasowej paliwa Hydrorafinat w różnych warunkach badania 
Hydroperoxides formation in jet fuels coming from different production processes.. Tworzenie wodoronadtlenków w paliwach lotniczych pochodzacych z różnych...

\section{Podsumowanie}

Przeprowadzone badania stanowiskowe i laboratoryjne wraz $\mathrm{z}$ otrzymanymi wynikami dla paliw lotniczych Merox i Hydrorafinat wskazują wyraźnie na zajście procesu ich degradacji termicznej. Testy stanowiskowe realizowano $\mathrm{w}$ różnych warunkach badania, tzn. w różnych temperaturach i prędkościach przepływu paliwa. Miarą oceny procesu degradacji badanych paliw było określenie liczby wodoronadtlenkowej i liczby kwasowej po poddaniu ich działaniu wysokich temperatur w instalacji stanowiskowej.

Zasadniczy proces tworzenia wodoronadtlenków dla obydwu badanych paliw zachodzi w temperaturze do około $350{ }^{\circ} \mathrm{C}$. Jednakże otrzymane wyniki pokazują, że na wartość liczby wodoronadtlenkowej ma wpływ technologia wytworzenia danego paliwa. Związane jest to $\mathrm{z}$ uszlachetnianiem paliwa lotniczego poprzez dodatek antyutleniacza, który odgrywa istotną rolę w ograniczaniu degradacji paliwa, ponieważ dodatek ten wyraźnie hamuje powstawanie wodoronadtlenków i obniża wartość liczby kwasowej. Dłuższy czas badania (mała wartość wydatku paliwa), a tym samym dłuższe oddziaływanie podwyższonej temperatury na paliwo nie zawierające dodatku antyutleniacza, sprzyja procesowi powstawania większej ilości wodoronadtlenków.

\section{Literatura}

[1] ASTM D3241 Standard Test Method for Thermal Oxidation Stability of Aviation Turbine Fuels, www.astm.org

[2] Anderson S.D. Edwards T. Harrison W.E.: U.S. Air Force Improved JP-8 Development Program - An Overview, 2nd International Symposium on Aviation Turbine Fuel Specifications, 11-13 May 1993.

[3] Datschefski G.: Critical review of the JFTOT, Aviation fuel: thermal stability requirements, ASTM STP 1138, P. W. Kirklin, P. David, Eds., American Society for Testing and Materials, Philadelphia, 1992.

[4] Sarnecki J: Jet fuels degradation under severe thermal loads, Journal of KONBIN, no 3 (31), pp. 31-40, 2014.

[5] ASTM D3703 Standard Test Method for Hydroperoxide Number of Aviation Turbine Fuels, Gasoline and Diesel Fuels, www.astm.org

[6] Sarnecki J.: Innowacyjne stanowisko badawcze do określania stabilności termicznej paliw lotniczych, Journal of Konbin, no 1(29), pp. 15-22, 2014.

[7] Sarnecki J. Gawron B. Kosiak A.: Dokumentacja ruchowa i oprogramowanie stanowiska badawczego do badań procesu degradacji termicznej paliw lotniczych, Sprawozdanie nr 2/55/2014, ITWL, 2014.

[8] ASTM D3242 Standard Test Method for Acidity in Aviation Turbine Fuel, www.astm.org

[9] Sarnecki J.: Raport końcowy z realizacji projektu nr 2011/01/D/ST8/06567 pt. „Badania nad mechanizmami i kinetyką procesu degradacji termicznej paliwa do turbinowych silników lotniczych. 
[10] Heneghan S. P., Zabarnick S., Ballal D. R. and Harrison W. E.: JP-8+100: The Development of High-Thermal-Stability Jet Fuel, Journal of Energy Resources Technology 118(3), 170-179, 1996.

\section{Wyniki otrzymane w ramach projektu badawczego nr DEC-2011/01/D/ST8/06567 finansowanego przez Narodowe Centrum Nauki}

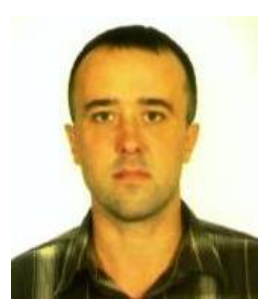

Dr inz. Jarostaw Sarnecki, absolwent Wojskowej Akademii Technicznej. Od 1999r. pracuje w Instytucie Technicznym Wojsk Lotniczych (1999-2002 - Zakład Diagnostyki Techniki Lotniczej, 2002-2006 - Zaktad Silników Lotniczych, od 2006 - Zaktad Materiatów Pędnych $i$ Smarów). Gtówne obszary zainteresowania: proces spalania paliw lotniczych, trybologia $i$ systemy diagnostyczne napędów statków powietrznych. Od 2007r. petni funkcje kierownika Zakładu Materiałów Pędnych i Smarów.

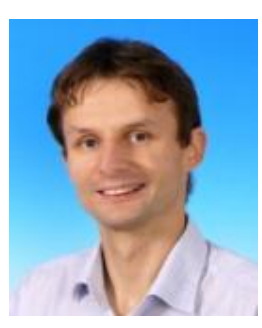

Dr ini. Bartosz Gawron, absolwent Wojskowej Akademii Technicznej na kierunku mechatronika, specjalność: samoloty $i$ śmiglowce, $w$ latach 2008-2012 doktorant na studiach III stopnia $w$ WAT na Wydziale Mechatroniki $i$ Lotnictwa, od 09.2012 doktor nauk technicznych $w$ dyscyplinie naukowej mechanika. Aktualnie pracownik naukowy w Instytucie Technicznym Wojsk Lotniczych.

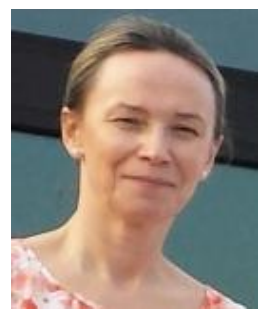

Mgr Jadwiga Gtąb, absolwentka Chemii, Wydziału Matematyki, Fizyki i Chemii Uniwersytetu Śląskiego. Od 1996 do 2011 kierownik Pracowni Paliw $w$ Centralnym Laboratorium Naftowym, a następnie w Instytucie Paliw i Energii Odnawialnej. Od 2011 roku starszy specjalista badawczo-techniczny Zakladu Materiatów Pędnych i Smarów w Instytucie Technicznym Wojsk Lotniczych. 